\title{
BIOSYSTEMATIC STUDIES ON SPERGULARIA MEDIA AND S. MARINA IN THE \\ NETHERLANDS IV \\ REPRODUCTION, DISSEMINATION, KARYOGENETICS AND TAXONOMY*
}

\author{
A. A. STERK \\ Hugo de Vries-Laboratorium, Universiteit van Amsterdam
}

\section{SUMMARY}

In this fourth and last paper on the biosystematics of the Dutch halophilous species of Spergularia, some relevant details concerning their reproduction and dissemination are discussed, the results of a karyogenetic investigation are reported, and, finally, the taxonomic interpretation of the acquired data is given. S. media and $S$. marina differ in their mode of reproduction; the latter normally reproduces autogamously in nature and the former both allogamously and autogamously. Dispersal of the seeds is by polychory. $S$. media and $S$. marina have $2 n=18$ and $2 n=36$ chromosomes respectively. Hybridisation apparently does not occur. The taxonomic confusion is shown to be chiefly caused by an insufficient insight into the degree of variation of certain characters, especially in the development of the seed wing, in both species.

\section{REPRODUCTION}

The mode of reproduction has a considerable influence upon the variation pattern of a population complex by determining to a large extent, among other things, the possibility of gene exchanges between neighbouring populations and also by being of primary importance in connection with processes of natural selection. To establish the method of reproduction is not always an easy matter (FRYXEL 1957), especially when a taxon can propagate itself by means of several types of reproductive processes, e.g., by autogamy and by allogamy. The contribution of each form of reproduction to the total propagating capacity of a taxon of this kind (the estimation of the percentage of "natural crossing") can only be established by means of genetic experiments (by artificial hybridisation). Moreover, the relative contributions may vary in dependence on micro-climatological factors and on the not necessarily constant activities of the pollinating insects.

During the present investigation, the following experiments were carried out with regard to the method of reproduction of $S$. media and of $S$. marina:

1. Flowers were encased in small insect-proof bags, so that any fertilisation

taking place was necessarily the result of selfing. Self-fertilisation produces viable seeds and a fertile progeny, so that self-incompatibility does not exist (at least not in the flowers used for these experiments).

* Published with financial aid from the Brumundfonds of the Royal Botanical Society of the Netherlands. 
2. Flowers were castrated and pollinated with pollen obtained from different plants. The resulting cross-fertilisation also yields a fertile progeny.

3. Functionally female flowers produce viable seeds and a normal progeny when artificially pollinated both with pollen taken from other flowers of the same plant and with pollen from a different plant.

4. Encased functionally female flowers and castrated normal flowers do not produce any progeny, so that agamospermy clearly does not occur (there was a theoretical possibility that in the experiments nos. 1 and 3 the pollen acted as the necessary stimulant evoking apogamy).

Progenies were reared from seeds gathered from individual plants of $S$. media in the field for the purpose of studying the genetic variability of the characters of the seed wing and the possible hereditary nature of the reduction of the androecium. In the progenies segregation was observed in both the degree of development of the seed wing and the degree of reduction of the androecial elements, which provides direct proof of the occurrence of cross-fertilisation in this species.

An investigation into the heredity of the floral colour, the mean number of stamens per flower, and the degree of development of the seed wing of S. marina showed that a progeny always resembles its parent plant and this points to selfing. Cross-fertilisation is of very rare occurrence in this species, but it must happen occasionally to account for the characteristic combinations of characters found in some populations, the functionally female flowers presumably being of considerable significance in this connection. Artificial crossings did not reveal any reproductive barriers between the different phenotypes of $S$. media recorded from the Netherlands; plants with urw-seeds crossed with plants with bvw-seeds, for instance, always yielded fertile descendants. The same holds, mutatis mutandis, for plants from different populations of $S$. marina.

An examination of the floral morphology and studies of the floral ecology contributed valuable indications concerning the mechanism of pollination (for details, see STERK 1968). The most important relevant data, are tabulated in table 1 .

The table shows the principal differences between the two species.

Table 1. Comparison of floral structure and floral ecology of S. media and of S. marina.

\begin{tabular}{llcc}
\hline Number & Character & $S$. media & $S$. marina \\
\hline 1 & diameter of flower & $10-13 \mathrm{~mm}$ & $5-7 \mathrm{~mm}$ \\
2 & mean length of ovary & $2.5 \mathrm{~mm}$ & $1.8 \mathrm{~mm}$ \\
3 & mean length of style and stigma & $0.7 \mathrm{~mm}$ & $0.7 \mathrm{~mm}$ \\
4 & number of stamens per flower & 10 & $2-5$ \\
5 & length of anther & $0.8-1.3 \mathrm{~mm}$ & $0.5-0.8 \mathrm{~mm}$ \\
6 & diameter of pollen grains (of 500 & $(50-) 73-103(-125) \mu$ & $(68-) 88-102(-125) \mu$ \\
7 & specimens) & $2-3$ & 1 \\
8 & anthesis (in days) & $7-8$ & $4-5$
\end{tabular}


a. The characters nos. 1-3 show that in $S$. marina the pollen-catching area is appreciably larger in respect of the flower size than in $S$. media. This is also apparent from a comparison of the fig. $1, n$ and $p$ with fig. $1, k$ and $m$, in STERK (1969b).

b. In the flowers of $S$. marina the anthers dehisce already in the bud stage. The stigmas are also mature at this stage and the position of the receptive part of each stigma is such that the anthers can easily come in contact with these parts, pollen transfer, i.e., selfing, thus automatically being assured (see fig. $1, f$ in STERK 1969b).

In $S$. media the anthers also dehisce in the bud stage, but usually the stigmas are not yet in the receptive stage and, at any rate, they remain erect with their receptive sides turned away from the anthers, thus avoiding self-pollination at this stage (see fig. 1, $\mathrm{k}$ in STERK 1969a).

c. The characters nos. 4-6 indicate that in $S$. marina the number of pollen grains available per ovule is considerably lower than in $S$. media. The mean number of seeds per capsule is about 90 in $S$. media as against 60 in $S$. marina.

d. The period of floral anthesis is appreciably shorter in $S$. marina than it is in $S$. media (character no. 7).

e. The duration of actual anthesis (the total time the flowers are open per day) is also much shorter in $S$. marina than in $S$. media (character no. 8).

A comparison of data relating to factors controlling the opening and the closing of the flowers indicates that $S$. marina is much more sensitive to certain microclimatological conditions than $S$. media. The percentage of flowers that fails to open altogether, when recorded in the same season, is much higher in populations of $S$. marina than in populations of $S$. media.

Finally, the production of nectar is much more abundant and also more conspicuous in $S$. media than it is in $S$. marina. The former species exhibits stronger entomophilous tendencies than the latter, and a preliminary comparative study indeed showed that the frequency of visits by pollinating insects to flowers of $S$. media exceeds by far that recorded for $S$. marina. The obvious conclusion is that the floral morphology of $S$. marina is indicative of a better adaptation to autogamy than the floral structure of $S$. media. However, notwithstanding the relatively frequent visits of pollinators to its flowers, the importance of self-pollination in $S$. media must not be under-estimated.

The rather advanced reduction in the number of androecial elements in $S$. marina, in other words, the available number of pollen grains per ovule, is most probably associated with the predominance of autogamy in this species. The chances of survival are apparently not unfavourably effected; on the contrary, the opposite may be the case and a selection may have been operative favouring the specimens with fewer stamens. Evidently plants utilising the available nutrients and their synthesising capacities most economically had an advantage over plants that did not employ their resources so sparingly and formed more stamens per flower. This conclusion is to some extent corroborated by the observation that plants, when in unfavourable circumstances, produce relatively fewer stamens per flower. This is a case of parallel development of a 
habitat-induced modification and a genotypic adaptation. After the reduction of the number of stamens to about 2 per flower, apparently an equilibrium was reached between the forces accomplishing an androecial reduction and the chances of survival (which are negatively influenced by a progressive reduction of the androecium).

\section{DISSEMINATION}

The manner of dissemination of the seeds (or of other diaspores) of a great many species can not so easily be established, especially polychorous species causing difficulties. The share of each disseminating agent in the dispersal of the seeds of a polychorous taxon is not so readily assessable and it may vary in the course of time. The study of dispersal in the two species of Spergularia under investigation is, moreover, complicated by the heteromorphism of their seeds. No special study of seed dispersal was undertaken, but the following relevant data and discussions have been gleaned from the pertaining literature. According to previous workers, both the winged and the unwinged types of seeds of $S$. media and of $S$. marina are polychorous, hydatochory, anemochory, zoochory (both endozoic transport by ducks and epizoic dispersal), and anthropochory having been reported (RIDLEY 1930; FEEKES 1936; DE VRIES 1961). The question can be raised in how far possible differences in the dispersal rate of winged and of unwinged seeds are of importance in the establishment of differentiations among the populations. At the present state of our knowledge, and owing to the complex nature of the dispersal of the seeds, no positive answer can be given as yet, however. The impression was gained that any differences in dispersal rates are not of great importance in this respect.

\section{KAR YOGENETICS}

Karyogenetic data, such as number, size and morphology of the chromosomes, may be of considerable importance in biotaxonomy (DAVIS \& HEYwOOD 1963). As a rule, different chromosome numbers constitute an effective reproductive barrier between populations.

The chromosome numbers of both species of Spergularia under investigation were studied by means of Feulgen-stained squashes of flower buds and root tips previously fixed in Carnoy's mixture ( 3 pts. of abs. alcohol; 1 pt. of glacial acetic acid) and preserved in $70 \%$ alcohol, and by means of microtome sections of root tips fixed in Karpechenko's fixative (paraffin wax technique, $15 \mu$, Heidenhain's hematoxylin staining). The results of these chromosome counts are shown in table 2.

The number of chromosomes of $S$. media appears to be $2 \mathrm{n}=18$ in all populations sampled throughout the area of study including all samples of specimens with unwinged seeds. This result is in good agreement with data obtained from material collected in Germany (WULF 1937), Scandinavia (NoRDENSKIOLD 1942), Portugal (Castro \& Fontes 1946; Rodriguez 1953), Gr. Britain \& 
Table 2. Chromosome counts of $S$. media and $S$. marina in material from the Netherlands.

\begin{tabular}{|c|c|c|c|}
\hline Species & $\mathbf{n}$ & $2 n$ & Locality \\
\hline S. media & & 18 & Zwin, Zeeuws-Vlaanderen \\
\hline S. media & 9 & & Spieringschor, N-Beveland \\
\hline S. media & & 18 & Ellewoutsdijk, Z-Beveland \\
\hline S. media & & 18 & Kwade Hoek, Goeree \\
\hline S. media & & 18 & De Grie, Terschelling \\
\hline S. media & & 18 & Boschplaat, Terschelling \\
\hline$S$. media (with unwinged seeds) & & 18 & Boschplaat, Terschelling \\
\hline$S$. media (with unwinged seeds) & & 18 & Oosterkwelder, Schiermonnikoog \\
\hline S. marina & & 36 & Zwin, Zeeuws-Vlaanderen \\
\hline S. marina & 18 & & Quarlespolder, Walcheren \\
\hline S. marina & 18 & & Kaloot, Z-Beveland \\
\hline S. marina & 18 & & Ellewoutsdijk, Z-Beveland \\
\hline S. marina & 18 & & Veere, Walcheren \\
\hline S. marina & 18 & & Ossendrecht, N-Brabant \\
\hline S. marina & & 36 & Kwade Hoek, Goeree \\
\hline S. marina & 18 & & De Grie, Terschelling \\
\hline S. marina (with winged seeds) & & 36 & De Grie, Terschelling \\
\hline S. marina & & 36 & Oosterkwelder, Schiermonnikoog \\
\hline S. marina & & 36 & Oostelijk Flevoland \\
\hline
\end{tabular}

Portugal (Blackburn \& Morton 1957), North Africa, Corsica, France and the Iberian Peninsula (MonNIER 1955, 1960b) and Tunesia, Spain, Portugal, France, Belgium and England (RATTER 1959, 1964). The form of $S$. media with unwinged seeds of Gr. Britain (the so-called "Lepigonum marinum Wahl. var. apterum Marshall") also has $2 \mathrm{n}=18$ (RATTER 1959) and the same form of Portugal, Spain and France, S. marginata ssp. angustata (Clav.) Monnier, likewise $2 n=18$ (MONNIER 1962). In material of $S$. marina consistently $2 n=36$ was counted. This is in good agreement with earlier reports: BLACKBURN (1933): England; RoHWEder (1939): Germany; Löve \& Löve (1942) and Nordenskiold (1942): Scandinavia; BlackBurn \& Morton (1957): England and Portugal; ReESE (1957): North Africa; Monnier (1960a): North Africa, Iberian Penins., France, Italy, Holland, Denmark; RATTER (1959, 1964): England, France, Spain, Portugal. A form of $S$. marina with winged seeds from Oulu (Finland) studied by the present author also has $2 n=36$ chromosomes. It is rather obvious that in the genus Spergularia the basic chromosome number $\mathrm{x}=9$. $S$. media is a diploid and $S$. marina a tetraploid species (RATTER $1959 ; 1964$ ). Experiments carried out by RATTER (1959) and confirmed by the present author show that hybrids between these two species can not be produced by crossing. Personal observations of the author at sites where the two taxa under discussion grow sympatrically did not show the presence of morphologically intermediate specimens and the conclusion can safely be drawn that under field conditions hybridisation does not take place either, contrary to reports in the literature of the occurrence of intermediates (HEGI 1964; RoTHMALER 1963). The reproductive barrier is no doubt primarily caused by the different chromosome numbers. 
Particularly in the older taxonomic literature the two species $S$. media and $S$. marina have often been confused, so that the specific delimitation and the nomenclature became muddled up.

LiNNAEUS (1762) mentions in his specific description of Arenaria media $(=S$. media) that the seeds are clearly winged. In his (LinNaeus, 1753) diagnosis of Arenaria rubra $\beta$ marina $(=S$. marina) he indicated exalate seeds as a character. Later descriptions of $S$. media by De CANDOlle (1804), Presl (1826) and KitTel (1844), and of $S$. marina by Presl (1819) and GrisebaCH (1843) also mention that $S$. media has winged, and $S$. marina unwinged, seeds. Later on, forms of $S$. media with exalate seeds were encountered which caused certain difficulties. When LOENNROTH (1854) discovered this form in Sweden he described it as a separate species under the name of Lepigonum fasciculare Loennr. This taxon was again described by Krause (in PRAHL 1890) as a variety of Spergularia marginata Kittel under the name of $S$. marginata var. fascicularis E. H. L. Krause, which name was taken up by AsCherson \& GraebNer (1919) and by Christiansen (1953). In Christiansen (1961), it is referred to as S. marginata forma fascicularis. When MARSsON (1869) came across specimens of $S$. media with exalate seeds from Pomerania (the German Baltic coast), he decided to merge this taxon with $S$. marina under the name of $S$. halophila Marss. Holkema (1870), who made a thorough study of the flora of the Dutch North Sea Islands, followed Marsson on the ground of the argument that the diagnostic character of "winged" (versus "unwinged") seeds is too inconstant to serve as a distinguishing taxonomic character. He added the annotation that "De geleerde Marsson door deze opgave aan eene groote verwarring een einde gemaakt heeft", i.e., that "the learned Marsson, by this proposal (viz., of recognising $S$. halophila), has put an end to a considerable confusion". The phenotype with exalate seeds was again described, from Britain this time, by Marschall under the name Lepigonum marinum Wahl. var. apterum (compare RATTER 1959). It has in the meantime been referred to as Spergularia marginata Kittel var. angustata Clav. by Clavaud (1882) - relating to French material - and appears as $S$. marginata ssp. angustata (Clav.) Monnier in MONNIER (1962); relating to material from France, the Iberian Peninsula and Morocco. A comparative study, during which assistance was kindly given by Dr. W. Christiansen (Kiel), who provided some herbarium sheets of "S. marginata f. fascicularis", and by Dr. J. A. Ratter (Edinburgh), who identified the form of S. media with unwinged seeds from Terschelling as " $S$. marginata var. apterum" and provided a sample of seed of this taxon from Britain, revealed that the so-called $S$. marginata f. fascicularis, as recognised in NW-Europe, and $S$. marginata var. apterum, as recognised in the United Kingdom, are taxonomically identical with the form of $S$. media with exalate seeds found in the Netherlands. A personal encounter with the unwinged form of $S$. media in the Danish islands of Skallingen and Römö convinced me of the identity of this form with the unwinged type of the Dutch populations. A direct identification of Dutch material 
with specimens from SW-Europe named $S$. marginata ssp. angustata has not yet been attempted, but the detailed and accurate accounts and illustrations in MONNIER (1962) leave, in my opinion, very little doubt about their taxonomic identity.

Summarising the evidence, the conclusion may be drawn that along the coasts of W. Europe and N. Africa a form of S. media with exalate seeds occurs which has been described as an infraspecific taxon under different names. In this area at least, the form in question has $2 \mathrm{n}=18$ chromosomes. The taxon $S$. marina, on the other hand, was supposed to be characterised by exalate seeds by a number of authors, see, e.g. Linnaeus (1753), Presl \& Presl (1819), and GRISEBACH (1843), but later on the occurrence of a form with a low representation of broadly winged seeds was discovered, see, e.g., the description of a var. heterosperma Fenzl of $S$. marina (in LEDEBOUR 1844). This form produces some winged seeds among the predominantly exalate ones. According to the Flora Europaea Vol. I, plants of $S$. marina that produce a low percentage of winged seeds apart from exalate ones are common throughout Europe.

LEBEL (1868) described a forma $\gamma$ australis of his Spergularia Dillenii $(=S$. marina), which produces a fairly large percentage of winged seeds. AsCHERSON \& GRAEBNER (1919) say of this form that there are 30-40 winged seeds per capsule. They describe the wing as "franzig-gezähnt", which characterises the seeds as seeds of S. marina. These authors do not state how many exalate seeds occur among the winged ones. This "var. australis" is recorded as occurring in the Mediterranean area.

Plants reared from seed received from the University of Oulu (Finland) under the name of $S$. salina, proved to belong to $S$. marina. These plants produce exclusively broadly winged seeds in their first-formed capsules and agree with plants with this character from Terschelling, also in their chromosome number $(2 n=36)$.

The above-mentioned evidence renders it highly probable that forms of $S$. marina with winged seeds occur along the coasts of W. Europe and the Mediterranean area. Judging from the scarcity of references to it in the taxonomic literature, this form is apparently rare (as it is in the Netherlands).

According to the Flora of Heimans, Heinsius \& ThiJSSE (1965), three halophilous species of Spergularia occur in the Netherlands, viz., S. marginata Kittel (= S. media), S. salina J. \& C. Presl (= S. marina), and S. media Fr. The distinction between $S$. salina and $S$. media Fr. is supposed to be a matter of different leaf characters: the leaves of $S$. salina are said to be biconvex and those of $S$. media convex below and flat above. However, the degree of convexity of the upper and lower leaf surfaces varies in a single specimen and is partly determined by the environment, so that it has no diagnostic value whatsoever, therefore the taxon "S. media Fr", as recognised in the flora, is identical with $S$. salina (i.e., S. marina). S. media Fr. is, in fact, a synonym of $S$. marina, compare FeEKES (1936) and STERK (1966).

It is striking that plants with winged and larger seeds occur next to specimens with exalate and smaller seeds in populations of both $S$. media and $S$. marina. 
This morphological parallelism between the two species is concomitant with an ecological similarity. The form of $S$. media with exalate, smaller seeds prefers disturbed habitats, whereas the form with winged, larger seeds occurs in more stable environments. $S$. marina is a species of disturbed sites and has unwinged seeds. Conceivably a similar selective pressure acting upon both species resulted in the appearance of populations with exalate seeds of both taxa in disturbed habitats. We can postulate in this connection that $S$. marina originally also had winged seeds and at a later phase of its existence as a taxon gradually retreated from the more stable habitats whilst becoming adapted to disturbed milieus (and the diminution of the size of the seed and the breadth of the seed wing taking place simultaneously). However this may be, the great rarity of the alate seed type of $S$. marina is presumably the result of plants with this type of seed being ousted out by selection in a disturbed environment, as is the case in S. media.

The infraspecific classification of $S$. media has also caused difficulties owing to its considerable phenotypic variation. Apparently the greatest number of forms occurs in North Africa; at least, MONNIER (1962) described five subspecies and a variety from this region, all with $2 n=18$ chromosomes. Each of these taxa is reported to have its own geographic distribution, as shown by Monnier's chorological maps, including $S$. marginata var. angustata (Clav.). Monnier which is taxonomically identical with the form of $S$. media with unwinged seeds found in the Netherlands. Flora Europaea Vol. I states under S. media: "Populations of this species with completety unwinged seeds occur in Britain, Ireland, France and probably elsewhere, and have been given varietal status by a number of authors". Clearly such names as S. marginata var. angustata Clav. and Lepigonum marinum Wahl. var. apterum (Lepigonum marinum $=S$. media) are intended here. The description in $F l$. Europ. can be read as meaning that all plants of such (local) populations have exalate seeds. The descriptions of $S$. marginata var. fascicularis E. H. L. Krause (the form of $S$. media with exalate seeds as found in NW-Europe) do not state explicitly whether all plants produce exalate seeds. In his Neue kritische Flora von Schleswig-Holstein, CHRISTIANSEN (1953) calls this form $S$. marginata var. fascicularis, but in his Flora der Nordfriesischen Inseln of 1961 he speaks of $S$. marginata forma fascicularis and this apparently means that in the North Friesian Islands the forma fascicularis occurs among the normal form, at least if this author uses the category of the "formae" in the customary sense. A personal study in the North Friesian Islands of Skallingen and Römö has shown that in the first named islands the populations are mixed and likewise in Römö, a population at Nörreland near Lakolk excepted where $99 \%$ of all capsules examined contained exalate seeds.

This survey of the recent floristic literature shows that the specimens of $S$. media with unwinged seeds have been classified as a forma, a variety, or a subspecies. DAvis \& HeYwood (1963) discuss the case in which a taxon behaves as entities of a different rank of the formal taxonomic hierarchy in different parts of its distributional area, and remark: "A complication is added by the fact that the same variant may occur as a sporadic form and as a local popula- 
tion. In such cases it is probably advisable to use varietal rank to cover both situations". In the Netherlands, populations of $S$. media exclusively consisting of plants with winged seeds occur, but also populations of a mixed character, whereas populations consisting only of plants with exalate seeds have not been found. If we, at least theoretically, distinguish all populations consisting of the "winged" type and all populations of the "unwinged" type as two distinct varieties, the situation in the Netherlands, and more particularly in the North Sea Islands, could be interpreted as follows: all local populations of $S$. media contain a mixture of these two varieties. From a biological point of view this solution is highly unsatisfactory, however, because in such populations crossfertilisation between the "varieties", and hence exchange of genes, takes place. From the standpoint of genetics, these populations are entities in which certain gene combinations (complexes of characters) occur with a certain frequency, and this renders the distinction between two components ("varieties") within such a population unnatural. Moreover, these so-called "varieties" gradually pass into one another in a population, so that the complex but more or less continuous, infraspecific variation of $S$. media, in this country at least, can not be satisfactorily described by means of the conventional categories of subspecies or variety. Also on account of practical considerations the above-mentioned recommendation of Davis \& Heywood is not followed here and only a description of the local variation per population as found in the various habitats is given. Holkema (1870) mentioned two infraspecific entities of $S$. media for the Netherlands, viz., the small-flowered form $S$. halophila Marss. $\gamma$ media 1. micrantha Marss. and a large-flowered one, $S$. halophila $\gamma$ media 2. macrantha Marss. In our country, the two forms are found in the same population. Presumably the group "micrantha" includes plants with smaller flowers which have a reduced androecium; Holkema does not make mention of an androecial reduction.

It has already been mentioned that, apart from the widespread form of $S$. marina with small exalate seeds which at best produces only a few winged seeds per capsule, a form occurs that produces larger, broadly winged seeds only (at least in the proximally formed capsules of each inflorescence). The latter form, which has apparently never been described before, has a very limited area in the Netherlands, viz., in a single locality in the island of Terschelling. This type always occurs in a mixed population with the exalate form and is, accordingly, not distinguished as a separate infraspecific taxon.

ASCHERSON \& GRAEBNER (1919) gave an extensive survey of the infraspecific variation of both species. They based the distinction of the various infraspecific taxa on the size of the inflorescence and the flower, the degree of seed wing development, the sculpture of the testa, the size of the plants, the degree of pubescence and the average term of life. Nearly all these characters are variable and can be observed in different individuals growing side by side in the same population. The so-called infraspecific taxa occur, at best, as formae in this country.

A character reported to be of considerable taxonomic significance in the 
genus Spergularia and also in the two species under discussion, is the sculpture of the testa which can be smooth or finely tuberculate. KINDBERG (1863) divided the genus Lepigonum (= Spergularia) into two sections as follows:

Sectio I. Leiosperma Kindb. : seeds smooth.

Sectio II. Trachysperma Kindb. : seeds tuberculate.

Kindberg included various binomials (under Lepigonum), now referable to $S$. marina and to $S$. media, in the section Leiosperma, but Lepigonum salinum, also referable to $S$. marina, was included in the section Trachysperma. Recently Kowal (1966) once more divided the genus Spergularia in two sections on the basis of the sculpture of the seeds:

Section 1. Tuberculatae Kowal: seeds with tuberculate testa.

Section 2. Rasiles Kowal: seeds with smooth testa.

He included both $S$. marginata Kittel ( $=S$. media) and $S$. salina J. et C. PresI in the Tuberculatae.

Population studies by the present author clearly indicate that the phenotypic variation of $S$. marina in this respect does not warrant a subdivision of the genus on the ground of the testa sculpture. In the same population both smooth and tuberculate seeds occur. Population studies carried out by MoNNIER (1953) in Morocco show that in that region individuals of $S$. media occur that produce both smooth and tuberculate seeds. The variation in $S$. media likewise pleads against such a subdivision.

According to Rossbach (1940), the species $S$. villosa (Pers.) Camb. and $S$. diandra (Guss.) Boiss. also produce smooth seeds as well as tuberculate ones, so that it is quite clear that a subdivision of Spergularia into sections distinguished by a different sculpture of the testa is altogether unacceptable.

The final conclusions that can be drawn from the taxonomic studies are as follows:

The taxa $S$. media and $S$. marina are, in the Netherlands, morphologically, karyogenetically and also ecologically distinguishable. The two species are reproductively isolated from one another. They are both very variable and in $S$. media an ecotypic differentiation within the population complex was demonstrable. The local populations of $S$. media and those of $S$. marina respectively are not mutually isolated by reproductive barriers. The confusion in the taxonomic literature concerning the two species was chiefly caused by an insufficient knowledge of the variability of these taxa.

\section{ACKNOWLEDGEMENTS}

This paper, the last one of a series of four, represents parts of the thesis for a Dr. Phil. degree prepared under the guidance of Prof. Lanjouw, State University, Utrecht. The author is much indebted to Prof. A. D. J. Meeuse, Hugo de Vries-laboratorium, University of Amsterdam, who translated the Dutch text.

\section{REFERENCES}

Ascherson, P. \& P. Graebne? (1919): Synopsis der Mittel-europäischen Flora 5 (1): 827-831, $832-837,851$. 
BLACKBURN, K. B. (1933): Notes on the chromosomes of the duckweeds (Lemnaceae) introducing the question of chromosome size. Proc. Univ. Durham Phil. Soc. 9: 84-90.

— \& J. K. MORTON (1957): The incidence of polyploidy in Caryophyllaceae of Britain and of Portugal. New Phytol. 56: 344-351.

Castro, D. \& F. C. Fontes (1946): Primeiro contacto citológico com flora halofila dos salgados de Sacavém. Broteria (Ser. Ciènc. Nat.) 15: 38-46.

Christiansen, W. (1953): Neue kritische Flora von Schleswig-Holstein: 209-210. Rendsburg.

- (1961): Flora der Nordfriesischen Inseln: 64. Hamburg.

Clavaud, M. A. (1881): Flore de la Gironde. Act. Soc. Linn. de Bordeaux 35: 403.

DAvis, P. H. \& V. H. HeYwood (1963): Principles of Angiosperm Taxanomy. London.

De Candolle, A. P. (1804): Flore de France 4: 793.

FEEKES, W. (1936): De ontwikkeling van de natuurlijke vegetatie in de Wieringermeerpolder, de eerste groote droogmakerij van de Zuiderzee. Ned. Kruidk. Arch. 46: 1-295.

FryXell, P. A. (1957): Mode of Reproduction of Higher Plants. Bot. Rev. 23 (3): 135-233.

Grisebach, A. (1843): Spicilegium Florae Rumelicae et Bithyniceae 1: 213.

HEGI, G. (1964): Illustrierte Flora von Mittel-Europa 3 (2): 786-789.

Heimans, E., H. W. Heinsius \& J. P. Thijsse (1965): Geillustreerde Flora van Nederland: 430-431. Amsterdam.

Holkema, F. (1870): De plantengroei der Nederlandsche Noordzee-eilanden: 38-40. Amsterdam.

KINDBERG, N. C. (1863): Monographia generis Lepigonorum. Nova Acta Scientiarum Upsaliensis 4: 1-44.

KitTel, M. B. (1844): Taschenbuch der Flora Deutschlands. 2. Aufl.: 1003.

KowAL, T. (1966): Studia systematyczne nadnasionami rodza jou Delia Dum., Spergula L. i Spergularia Presl. Monographiae Botanicae 21: 245-270. Warszawa.

LEDEBOUR, K. F. vON (1844): Flora Rossica 2: 168.

LinNaeus, C. (1753): Species Plantarum: 423.

- (1762): Species Plantarum ed. 2: 606.

LOENNROTH, K. J. (1854): Observationes criticae plantas suecicas illustrantes. Ups. Diss. Acad. Upsaliae.

Löve, A. \& D. Löve (1942): Chromosome numbers of Scandinavian plant species. Bot. Notiser: 18-59.

MARSSON, TH. FR. (1869): Flora von Neu-Vorpommern und den Inseln Rügen und Usedom: 77-78. Leipzig.

MonNIER, P. (1953): Sur quelques spergulaires du Maroc appartenant au groupe de Spergula marginata (DC.) Murb. Rec. trav. lab. Bot. Geol. Zool. Montpellier série Bot. 6: 77-88.

- (1955): Introduction à une révision du genre Spergularia (Pers.) Presl au Maroc. Bull. Soc. Sc. nat. et phys. du Maroc 35: 145-163.

- (1960a): Biosystématique de quelques Spergularia méditerranéens. Compt. rend. l'Ac. Sc. 250: 4429-4431.

- (1960b): Biosystématique de quelques Spergularia méditerranéens. Compt. rend. l'Ac. Sc. 251 : 117-119.

- (1962): Biogéographie et micro-évolution chez Spergularia marginata Kittel dans le bassin méditerranéen occidental. Afrique du Nord notamment. Rev. Cyt. Biol. Vég. 25 (3-4): 325-335.

NoRdenskiold, H. (1942): Cited in Löve, A. and Löve, D. 1942. Chromosome numbers of Scandinavian plant species.

Prahl, K. von, R. von Fischer Benzon \& E. H. L. Krause (1890): Kritische Flora der Provinz Schleswig-Holstein 2: 30.

Prest, C. B. (1826): Flora Sicula: 161. Prague.

Presl, J. S. \& C. B. Presl (1819). Flora Cechica: 94-95.

RATTER, J. A. (1959): A cytogenetic study in Spergularia. Thesis. Liverpool.

- (1964): Cytogenetic studies in Spergularia I. Notes Royal Bot. Gard. Edinburgh 25 (3): 293-302.

- (1965): Cytogenetic studies in Spergularia II. Notes Royal Bot. Gard. Edinburgh 26 (2): 203-236. 
Reese, G. (1957): Ueber die Polyploidiespektren in der nord-saharischen Wüstenflora. Flora 144: $598-634$.

RIDLEY, H. N. (1930): The dispersal of plants throughout the world. Kent.

RoDRIQUEZ, J. E. DE M. (1953): Contribucao para o conhecimento cariologico das halofitas e psamófitas litorais: $72-4$. Thesis.

RoHWEder, H. (1939): Weitere Beiträge zur Systematik und Phylogenie der Caryophyllaceen. Beih. Bot. Zbl. 59: 1-58.

Rossbach, R. P. (1940): Spergularia in North and South America. Rhodora 42: nos. 495-498.

Rothmaler, W. (1963): Exkursionsflora von Deutschland. Krit. Ergänzungsband Gefässpfl.: 121. Berlin.

STERK, A. A. (1966): Some remarks on the variability of Spergularia marginata and Spergularia salina in the Netherlands. Proc. Kon. Ned. Ac. Wetensch. C 69: 50-57.

- (1968): Een studie van de variabiliteit van Spergularia media en Spergularia marina van Nederland. Thesis Utrecht. 156 pp.

- (1969a): Biosystematic studies on Spergularia media and S. marina in the Netherlands I. The morphological variability on S. media. Acta Bot. Neerl. 18: 325-338.

- (1969b): Biosystematic studies on Spergularia media and S. marina in the Netherlands II. The morphological variability on S. marina. Acta Bot. Neerl. 18: 467-476.

- (1969c): Biosystematic studies on Spergularia media and S. marina in the Netherlands III. Acta Bot. Neerl. 18: 561-577.

Tutin, T. G., V. H. Heywood, N. A. Burgess, D. H. Valentine, S. M. Walters, D. A. WEBB (1964): Fl ra Europaea 1: 155. Cambridge.

VRIES, V. DE (1961): Vegetatiestudie op de westpunt van Vlieland. Thesis. Amsterdam.

WULF, H. D. (1937): Karyologische Untersuchungen an der Halophytenflora SchleswigHolsteins. Jahrb. Wiss. Bot. 84: 812-840. 